\title{
THREE ETHICAL DIMENSIONS OF THE FINANCIAL CRISIS
}

\author{
Antonio Argandoña
}




\title{
THREE ETHICAL DIMENSIONS OF THE FINANCIAL CRISIS*
}

\author{
Antonio Argandoña ${ }^{1}$
}

\begin{abstract}
It has often been said that the financial crisis in which the world economy has been immersed since mid-2007 is an ethical crisis. By studying the behavior of the agents who made the decisions that led to the crisis, we do find evidences of many unethical mistakes. But bad conducts were also present before the crisis and in countries not affected by it: the fact that the crisis has an ethical dimension does not mean that this is its only cause. In this paper, we argue that this crisis is a crisis of leadership or governance in a wide range of institutions, and this, in turn, reflects the failure of an economic and social model grounded on certain anthropological and ethical assumptions, and it is these assumptions that have failed.
\end{abstract}

Keywords: Ethics, Financial crisis, Firm, Social ethics.

* Note: Presented at the 1 ${ }^{\text {st }}$ EIASM Workshop on Business Ethics, Brussels, 10-11 November 2011.

\footnotetext{
${ }^{1}$ Professor of Economics, "la Caixa" Chair of Corporate Social Responsibility and Corporate Governance, IESE
} 


\title{
THREE ETHICAL DIMENSIONS OF THE FINANCIAL CRISIS
}

\author{
"Crisis means that certain postulates are exhausted and that certain \\ ways of coping with life are no longer relevant to emerging issues. \\ In my view, the crisis makes man tremble deeper when that \\ obsolescence affects the idea of progress"
}

(Polo 1991, 25).

\section{The financial crisis ${ }^{1}$}

In the summer of 2007, financial markets were shaken by the first episodes of what would become a serious financial crisis. ${ }^{2}$ Certain financial institutions in the US experienced an increase in mortgage loan defaults, especially in the so-called subprime segment. The fact that ownership of those loans had been transferred to other investors, or used to guarantee other assets (securitization), generated considerable suspicion about the true value of these assets and the level of risk involved, which, coupled with a lack of transparency, also raised doubts about the solvency of the institutions that owned them, as well as many other institutions connected as counterparties to these operations. The international financial system was very quickly affected by a serious crisis, which was first a liquidity crisis, as investors stopped lending to almost all entities, and then a solvency crisis. Moreover, the problem quickly spread to other markets and countries through contagion.

\footnotetext{
${ }^{1}$ This article forms part of the activities of the "la Caixa" Chair of Corporate Social Responsibility and Corporate Governance, IESE Business School, University of Navarra.

${ }^{2}$ A financial crisis is a situation in which there are serious changes in the value of financial institutions' assets, their access to financing, or the confidence of their customers, to the extent that the sustainability of the financial system is in danger. See Abberger and Nierhaus (2008), Claessens et al. (2008), Mendoza and Terrones (2008).
} 
From the beginning, central banks provided liquidity to the banks, but this could not solve the main problem, which was the loss of confidence in the soundness of the institutions involved. Governments therefore adopted extraordinary measures to recapitalize and clean up the banks' balance sheets. The situation seemed to be contained until, in September 2008, the bankruptcy of the investment bank Lehman Brothers put the global financial system on the brink of a widespread collapse, caused by panicking investors. The governments' actions allowed them to overcome this critical phase of the crisis, which had already triggered a deep recession.

To address the banking system's problems and emerge from the recession, governments introduced generous fiscal stimulus programs. These led to large amounts of public deficit which, combined with the high level of debt that some countries had already accumulated, generated a sovereign debt crisis led by Greece but followed closely by other countries.

All this demonstrated the interconnection between various crises and their remote origins (Gross 2007, Hoffman et al. 2007, Kindleberger 1978). For years, the overly lax monetary policy of the United States Federal Reserve had been creating a housing bubble in the United States (Bhattacharya and Yu 2008). The overvaluation of assets, high debt and a feeling of euphoria gave rise to the first crisis, which began, as already noted, when the growth of housing prices stopped, slowing demand and causing many customers to default. This crisis was also reproduced, in various ways, in other European countries, as a result of the similarly lax policy of the European Central Bank.

The second crisis arose from the bursting of the bubble and its impact on the balance sheets of financial institutions: loss of asset value, increase in bad debts, funding difficulties, and lack of capital. This crisis occurred not only in countries where a bubble had formed, such as the US, Britain, Spain and Iceland, but also in others, such as Germany and Belgium, whose banks had invested in 'toxic' assets. It was also compounded in some cases by a currency crisis, when the domestic currency depreciated, sharply increasing the debt levels of households, firms and financial institutions, as happened in Iceland.

The third crisis was a sovereign debt crisis, and was caused by the high debt incurred by governments through their fiscal stimulus measures and the support given to troubled banks in an environment of high private sector external debt. The possibility of default by some governments created a new wave of mistrust, raising the risk premium and forcing these governments to implement tough fiscal consolidation plans, which aggravated the recession and the difficulties of their banks.

The preceding paragraphs provide a brief history of the recent financial crisis ${ }^{3}$ that, like all complex phenomena, has economic, psychological, social, political and ethical causes: they are interdependent. Some analysts blame governments and central banks, for their lax monetary policy in the years before 2007, as well as the regulators and controllers of the financial system, ratings agencies, managers of financial institutions, mortgage sellers, home buyers, developers and builders, and so on.

\footnotetext{
3 There are many excellent analyses of this crisis, for example, Baily et al. (2008), Blundell-Wignall et al. (2008), Bordo (2008), Brunnermeier (2008), Diamond and Rajan (2009), Eichengreen (2008), Gross (2009), Hellwig (2008), Kane (2008), Morris (2008), Taylor (2009a, b), Tett (2009).
} 
It has often been argued that this is an ethical crisis, ${ }^{4}$ because moral errors may explain why economic and political failures can lead to situations of crisis. To explain this, we will develop our analysis on three levels. The first concerns the moral failings of individuals, manifested in inappropriate behaviors that can lead to a crisis. The second is the organizational level: because the strategies and cultures of non-financial companies, banks, investment funds, rating agencies, central banks, regulators and supervisors, and governments show the existence of ethical lapses at an organizational level. The third level is that of social and theoretical ethics, whose failures have hampered corrective mechanisms or aggravated the moral consequences of individual or organizational decisions.

The following section of this paper discusses a repertoire of morally wrong or questionable behaviors arising during the recent crisis. In attempting to introduce these behaviors into the operation of financial organizations, we wonder to what extent the ethical crisis was also, perhaps above all, a crisis of management or governance of these entities. This will take us to an analysis of the concept of ethics that emerges in these explanations, and which will shed light on the nature of the deeper social problems that have arisen in the crisis. The article ends with conclusions.

\section{Personal ethics}

In this section, we review some of the behaviors that refer in one way or another to the actions that have led to the crisis (Argandoña 2009, 2010a, b, c, Graafland and van de Ven 2011, Hawtrey and Johnson 2009). It is not, of course, an exhaustive analysis, but only a quick inventory showing that the moral dimension has indeed been present in the crisis. ${ }^{5}$

It has been said, over and over again, that the cause of the crisis was greed, defined as a selfish and excessive desire for more of something (such as money) than is needed. A distinction should be made between this vice and legitimate economic rationality, which takes advantage of opportunities, such as buying when prices are low and selling when high, or taking on debt when interest rates are low (Miller 2009). ${ }^{6}$

The list of trampled virtues also includes temperance and, specifically, the ability to restrain the desire for success, wealth or social recognition, which thus become obstacles to proper professional conduct, and cowardice, complicity and lack of strength: for example, some managers, despite realizing what was happening, evaded some difficult decisions that might have jeopardized their career or their remuneration. And there were also behaviors of pride, arrogance and hubris among financiers, but also among economists, regulators and governments; all convinced that their knowledge and skills were superior, that they had no reason to submit to the supervision of others, or that they were above the law. In short, they placed a high value on honor, glory, wealth, fame and everything else that could have been achieved through professional excellence, but also through lies, and showed that they were more willing to lie than to restrain their desires or reorient their values (Torres 2009).

\footnotetext{
${ }^{4}$ Widespread ethical failures have been reported after all the episodes of boom, euphoria and subsequent financial crisis. See, for example, Bogle (2006) and Kindleberger (1978).

${ }^{5}$ Based on interviews with a group of managers before the crisis, Coleman and Pinder (2010) identified attitudes such as a preference for the short term, the transient bias ('this time it's different'), the ability to cope with risks, consideration of hedging as unnecessary, and so on.

${ }^{6}$ On the extent of greed and avarice in the business world, see Handy (2002), MacIntyre (1995), and Solomon (1992).
} 
And all this led to situations of injustice (Hawtrey and Johnson 2009), specifically commutative justice (Pieper 1966): withholding information, misleading advertising, multiplication of unnecessary operations (churning) to generate higher commissions, manipulation of stock recommendations, etc. Or in omitting the consideration of the common good: for example, moral hazard problems, when financial institutions take advantage of the limitation of their risks, thanks to the legal provision of limited liability or the existence of guarantees that limit their losses (Sinn 2008).

Prudence or practical rationality is the main virtue of the banker (Termes 1995), but it is difficult to exercise it in an environment of high growth, low interest rates and extraordinary opportunities for profit, leading to higher leverage and a reduction in the perception of risk; all of which constitute the perfect environment for poor management. There are many manifestations of such recklessness. Complacency, for example, is common in the boom phase (Lo 2008), ${ }^{7}$ and herd behavior, which can be rational, can also increase volatility. This volatility can then spread to other markets, leading to panic, attributable once again to herd behavior.

This brief summary of immoral behavior shows, as we said before, that the crisis has an ethical dimension. However, these vices are always present in one way or another in all human activity. And a cause that is present irrespective of whether or not the effect occurs cannot be a satisfactory explanation. ${ }^{8}$ To put it another way: if many agents have been motivated by greed in many places and for centuries, why did the crisis occur now and in these countries, and not at other times and in other places?

One answer to this question might be based on the generalization of these behaviors, which have exceeded a certain threshold above which we cannot guarantee the stability of the results. We have no empirical evidence on this, although there might have been social, legal and institutional changes which accentuated the role of greed and other vices. For example, the economic conditions for the formation of a bubble can generate abnormally high incentives (earnings expectations). There may have been a change in the society's values, giving rise to situations of 'induced greed' by encouraging and rewarding those who succeed in their greedy behavior and making it harder to behave otherwise: "greed is good". ${ }^{9}$ A particular case of this 'moral contagion' could be the institutionalization of these actions, for example, in the rules of behavior of firms, regulators and financial intermediaries.

On the other hand, society has long developed protective mechanisms, not against immoral behavior itself but against its consequences, ranging from law, courts and fines to the social rejection of offenders. It is possible that these social mechanisms have relaxed in recent years, ${ }^{10}$ and this brings us to the next level of ethics.

\footnotetext{
${ }^{7}$ A typical case is to consider that unlikely events are, in practice, impossible (Taleb 2007).

${ }^{8}$ Miller (2009) concluded that this was not an ethical crisis, because the behaviors listed in the text were the rational response of economic agents to changes in their environment that they did not cause. This theory is correct, in the sense that you cannot judge moral behavior without taking into account the agents' incentives, knowledge and circumstances, but it is incorrect insofar as it suggests that economic actions are not ethical but purely technical, i.e., that the 'rational' response of the agents cannot be subject to moral evaluation.

${ }^{9}$ The famous phrase of Gordon Gekko, the protagonist of the movie Wall Street (1987).

${ }^{10}$ The high yields of greed and low social protection have led to a proliferation of fraud, scams and hoaxes, which did not cause the crisis, but are one of its most striking symptoms. The frauds of Bernard Madoff and the like also highlight other moral weaknesses: pride (the desire to feel privileged, as part of an elite group of investors), recklessness (trust in the qualities of an expert, not subjected to verification) and some obfuscation (the 'desire' to believe that it is possible to have abnormally high returns over long periods of time).
} 


\section{The ethics of organizations}

The crisis we are looking at is often presented as a crisis of leadership or governance in organizations as varied as commercial and investment banks, hedge funds, monolines, rating agencies, supervisory bodies, central banks and governments. ${ }^{11}$ For example, there have been cases of bad governance and lack of professional competence on the part of directors, senior managers and analysts in organizations of all kinds. Often, the role of assets analysis and valuation, and even buying or selling decisions, was entrusted to young professionals with no experience in finance, who used sophisticated models based on overly simplistic assumptions, but nobody dared criticize them because nobody had better models. ${ }^{12}$ Furthermore, their superiors did not know what their subordinates were doing, they did not understand the models they were using, and they did not exercise adequate oversight. In other words, there was a lack of "an understanding of the mechanisms of structured products combined with the economic knowledge to put them in context and the management skills to run the organizations that marketed them" (Jay 2009a). ${ }^{13}$

These failures were manifested mainly in risk analysis and management, leading to "key personnel in virtually all major financial institutions [...] taking excessive risks" (Crotty and Epstein 2008, 4; cf. Hawtrey and Johnson 2009). There were many reasons for this. The financial institutions, for example, had established rigorous mechanisms for defining and monitoring these risks, but these were based on overly optimistic assumptions, built on the hypothesis that catastrophic events or 'black swans' (Taleb 2007) were highly unlikely and therefore could be omitted. The mechanisms for covering the portfolios' risks were based on evidence of recent decades, which were particularly stable in many of these markets, and also assumed that the risks of various assets were largely independent of each other; an assumption that was clearly proven false. These assumptions created the illusion that risk had been eliminated from the institutions' portfolios by the Credit Default Swaps (CDS), without allowing for the fact that this risk was re-introduced in other ways. They had created great public offices for supervision and control, but each was acting locally, meaning that no-one was supervising systemic risk. In addition, they had eliminated or mitigated various mechanisms and institutions established to monitor its effects. ${ }^{14}$

It has often been argued that the crisis was due to the creation of perverse incentives in the management of financial institutions. Incentives, financial or otherwise, are intended to promote certain behaviors that are expected to lead to desired results, but they can also cause unwanted effects, perhaps because they are poorly designed, such that unwanted results are rewarded ("the folly of rewarding for A when hoping for B"15): for example, they reward an increase in the share price in the short term rather than the achievement of greater value in the long term; or because they are manipulated by those who will benefit from them; or because they assume that agents are only motivated by economic interests, so that the introduction of

\footnotetext{
${ }^{11}$ On the supervisory institutions' share of the blame, see Levine (2010).

12 The question of economists' and financial theorists' responsibility deserves careful examination. See Acemoglu (2009), Caballero (2010).

${ }^{13}$ The complexity of certain financial instruments need not be morally problematic if we know the nature of the challenges that this complexity can create, and we act accordingly.

${ }^{14}$ Due to, among other reasons, political pressure from the regulated entities themselves, for example, concerning regulation of over-the-counter operations (Kane 2008).

${ }^{15}$ That is the suggestive title of the article by Kerr (1975). See also Rosanas (2006).
} 
incentives of this nature crowds out other possible targets, such as the quality of their work or the creation of teams which are effective in the long term. ${ }^{16}$

It is likely that many of the inappropriate behaviors in the recent crisis are related to the existence of perverse incentives. For example, the attempt to align the interests of managers and analysts with those of shareholders has led to compensation systems that emphasize shortterm results, which may have led to undesirable behaviors such as excessive risk-taking and manipulation of financial results or the stock price. ${ }^{17}$ In any case, the design and implementation of these remuneration systems was also reckless and a sign of bad governance, precisely because those undesirable results were not anticipated.

A particular case of perverse incentives would be the conflicts of interest that have arisen, for example, in the rating agencies, whose income depended in large measure on the valuation of their clients' assets (as well as other problems, such as the inadequacy of their models, the lack of a sufficiently long and varied history to incorporate in those models' parameters, and the fact that their best analysts ended up being hired by their clients, which accentuated the conflict of interest).

The crisis also entailed other problems, such as 'regulatory arbitrage', which moves operations to countries with lax controls or changes the nature of operations to circumvent the regulations. Also, the lack of transparency (opacity of operations, concealment of information from customers, regulators and even shareholders, etc.) is another characteristic of many of the behaviors that led to the crisis.

The regulation and control mechanisms also failed: changes such as the abolition of the GlassSteagall Act in the US, a law which separated commercial banking activity and investment; incentives for subprime mortgage lending, by companies under the patronage of the state, such as Fannie Mae and Freddie Mac in the United States; resistance to regulation of some financial derivatives, and so on. And these are not just technical problems, because these mechanisms are created and managed by people and, therefore, they are also decisions with an ethical dimension.

\footnotetext{
${ }^{16}$ Some examples of perverse incentives in the current crisis: 1) The compensation of mortgage brokers in the United States was based on the volume of loans, not probable solvency; this fostered a high-risk concession of this type of credit (and even the falsification of information in applications). 2) The banks that granted the mortgages quickly securitized them and took them off their balance sheets, thus reducing the need to monitor their customers' situation and follow loan repayments, at least in part. 3) Some debtors bought their houses with the intention of soon defaulting on payments and re-mortgaging when house prices rose. 4) Financial institutions often incurred in 'moral hazard' problems, leading to overly risky operations, with the explicit or implicit government guarantee of their liabilities. 5) The investment banks, which had been unlimited liability companies (private partnerships), became limited liability (public corporations), thereby reducing their liability for losses, which encouraged higher-risk strategies. 6) The growth of directors' and managers' compensation, often based on stock options, led them to seek short-term profitability, including through accounting fraud or manipulation. See Kane (2008).

${ }^{17}$ The high salaries of executives and financial analysts have often been presented as the cause of the crisis, but they appear rather to have been an effect of the speculative bubble: money goes to whatever is fashionable, and in recent years this meant real estate and financial assets. And where money goes, prices increase, and this generates extra profits (rents) that the various actors involved try to capture. Managers have a comparative advantage when it comes to knowing what those profits are, where they are generated and how to capture them, and the same applies to analysts and other experts, whose contribution is necessary for the creation of these rents.
} 


\section{The social dimension of ethics}

Earlier, we mentioned personal and organizational ethical lapses by agents who succumbed to the temptation of very favorable financing conditions. This already provides one explanation of why this is a moral crisis. But we have also noted that social conditions were also created that probably encouraged - or at least did not stop - these behaviors, and impeded the functioning of legal, institutional and social mechanisms which, in other circumstances, would have slowed the effects of those behaviors. What we offer here is not a complete analysis, but just some suggestions that try to explain why this is an ethical crisis, and why the ethical dimension is needed to avoid a recurrence.

Some experts (economists, but also moralists) deny that ethics play a role in the current crisis. According to the anthropological model that inspired neoclassical economics, the agents start with some given preferences, which economic science takes as data (Aranzadi 2006). Everything that makes a rational agent in this model is ethically neutral (Miller 2009); there is an absolute separation between ethics and economics ('separation thesis') (Harris and Freeman 2008). Ethics deals with values that are subjective and which cannot be assessed objectively, while economics deals with facts (Keynes 1890, Robbins 1935). The rational agent, who maximizes his utility subject to the usual restrictions, is not undertaking ethically relevant actions: economics is an amoral exercise. Or, to put it another way: if the market takes care of the self-regulating economic relations, individual actions, which ethics regulates, are not important; whatever the conduct, the market will find a social optimum (Zamagni 2009).

If this is so, the crisis was caused by the fortuitous confluence of events such as a credit expansion sustained for too long, some financial innovations and an array of failures in the monitoring, prevention and control mechanisms that had been created. ${ }^{18}$ In any case, the people to 'blame', if anyone, will be the consumers, entrepreneurs, analysts and executives of financial institutions who did not act rationally (not easy to identify because, a priori, their behavior could agree with economic rationality, even though the results were disastrous); the governments, which altered the incentives and constraints of private agents, pursuing unsustainable policies (e.g., giving poor people access to the housing market, or the suppression of certain financial regulations); and the supervisors and regulators who did not do their jobs.

In some sense, this moves the problem to the realm of politics, which has changed its moral position, at least in Western societies. ${ }^{19}$ Throughout modern times, these societies have set up political projects oriented towards rational and universal purposes: freedom, equality, development, welfare... But now those political goals have been met, and there remain fewer collective tasks to perform. "The rationalization of the means has replaced the ideal of rational ends [...] The result is, to a large extent, fragmentation: there are no common goods, the pursuit of social goals is a thing of the past, inequality invites creativity and competition" (Flamarique 2010, p. 107), and it was this same creativity and competition that gave rise to many of the financial innovations that later led to the crisis.

\footnotetext{
18 "The reasonable explanation for a crisis of this magnitude [...] is that a combination of a number of complex and highly interrelated factors have strongly contributed to this global financial turmoil. The factors are related to economic elements, to the corporate governance of banks and financial institutions, to the United States Government's monetary policy, to the lack of rigorous supervisory controls in the banking industry and financial markets, to the high leverage credit culture of people in the United States and the United Kingdom, to the banking management culture and philosophy, to the role played by the rating agencies" (Pezzuto 2008, pp. 6-7).

${ }^{19}$ This point has been developed by Flamarique (2009, 2010).
} 
The important thing here is the change in attitudes that has occurred, not whether this explanation is entirely valid or not. Citizens of rich countries tend to attribute to the State and to the market the role of guaranteeing their economic and social rights (employment, pensions, health, safety, etc.), and give up an important part of their autonomy in these areas, in exchange for a certain security in their living standards. The economic world is, again, a technical world, which works with its own rules and which has no reason to be guided by ethics. Our hope is that this world materialize a perfect productive, organizational and regulatory structure "which makes its citizens" honesty superfluous” (Pérez-Soba 2011, p. 6).

At least until the outbreak of the crisis, "in political life, boredom is detected in the same way in which the procedures of election, representation and distribution of welfare operate smoothly, but also within immovable limits. Public attention has turned to other things. It is not that expectations were not met: in essence, citizens are comfortable with the institutional regime. It is rather that the expectations are now individual, not universal" (Flamarique 2010, p. 107). The citizens are now individualists, to an extent that has probably not occurred in the past, and so is their ethics: they no longer have to deal with major social and political tasks, except perhaps for humanitarian actions in other countries. "The dream of a definitely just future society has died; the time of revolutions has passed, but the number and intensity of our desires have increased (...) While the idea of equality and social rationality rules the imagination that sustains our system and political culture, popular culture invites private codes, individual criteria" (Flamarique 2010, p. 108). It is the time of increasingly individualistic 'new rights'.

And, at the same time, emotions become the space in which the citizen can be 'himself', which means giving priority to the moment, the fleeting, and the fashionable. ${ }^{20}$ Ethics becomes 'emotivist' (MacIntyre 1981, Taylor 1989); what is 'authentic' becomes now 'moral'; the emotional response wins over trial and reflection, and it arbitrates all responsibilities. Citizens are willing to admit that we are all responsible for everything (Jonas 1984), but this is just a subterfuge for denying the sense of personal responsibility: responsibility is transferred to the collective and, ultimately, to the State. ${ }^{21}$ Again, private life, presumably guided by sentiment, authenticity and experiences, is divorced from public ethics.

But now the meaning of public ethics itself is changing, because these private rights, which citizens claim as necessary and inalienable for their self-realization, have lost their ethical support and are only upheld by law. In public discourse, ethical values become blurred: they are reduced to the private sphere, to the point of considering that democracy requires moral relativism, and that the existence of solid values must be rejected as fundamentalism.

\footnotetext{
20 "There is a gap between what is done, which belongs to the realm of the 'exterior', and the 'inside' world of feelings, centered in a weak sense of intimacy. Sentimental man 'locks' himself in a way to his 'feelings' (...) quite separate from social relationships" (Pérez-Soba, 2011, p. 7).

${ }^{21}$ The use of law and institutions is the first recourse, for example, when trust is in crisis. In a financial world in which relationships multiply and become depersonalized, trust is placed in the law (I can trust my bank, because the law requires it to act according to legal standards), in institutions (for example, the deposit insurance agency) and in the self-interest of financial institutions themselves ("the first and most effective line of defense against fraud and insolvency is counterparties' surveillance. For example, JPMorgan thoroughly scrutinizes the balance sheet of Merrill Lynch before it lends. It does not look to the Securities and Exchange Commission to verify Merrill's solvency") (Greenspan 2007, quoted by Kay 2009b). But all this collapsed. The law by itself cannot build trust: indeed, if the law is effective, then trust is not needed, but if it ceases to be effective, what can we trust in? (Rosanas and Velilla 2003). Nor can we rely on the entities' capacity for self-regulation, because they have so clearly neglected their duties.
}

8 - IESE Business School-University of Navarra 
At the same time, in a multicultural society, one must accept the plurality of values and, therefore, cultural relativism and, later, moral relativism. However, a system of ethics based on changing and relative values ends up judging only on its results. This, in politics, has two consequences. In the first place, it leads to disenchantment, because giving voice to everyone merely leads to cacophony, and a feeling that individuals' private demands are not met. Politics, when it leaves its technical and economic environment without the support of ethics, becomes volatile, ambiguous.

Second, the traditional means of political representation (unions, parties) give way to new social movements that are occasional (citizens join only for the defense of a personal interest that they value) but with claims to generality (all interests, however particular, become a social interest, and acquire the supposed right to enter society's moral agenda), and create new homogeneities (consumption as a social equalizer: the democratization of luxury), albeit subject to media and commercial manipulation.

If this is true, at least in part, then the cause of the crisis will be that 'someone' (politicians, bankers, experts) did not fulfill some technical duties that become moral duties when they are understood as the obligation to generate the outcomes of welfare, safety, growth, etc. that the citizens demand..$^{22}$ And this explains citizens' confusion about the current crisis: the rise and duration of unemployment, decreasing job security, difficulties in sustaining the welfare state, widespread uncertainty, etc., show that the market and the State have not fulfilled their part in that 'division of labor' between the public (economic prosperity, welfare state, security) and the private. And the worst of this is that the problem is not transient, despite the promises of governments, central banks and economists, that the next package of measures will be effective. And, furthermore, the cause of the crisis can no longer be attributed to external events, but to the behaviors of the very citizens who complain about the crisis, such as aging populations, the breakup of the homogeneity of cultural models, and even climate change.

Everything suggests that the economic systems, supposedly self-sufficient and self-regulating, are neither. The intended solution is regulation: the State must intervene to limit abuses that can occur in the market's functioning (Polo 1993). And this intervention must be undertaken not only as a technical duty but as a moral obligation, because its citizens ask for it, precisely to ensure the efficient functioning of the economic system and to avoid excessive volatility.

What ethical instruments are available to address these problems? Not, of course, private ethics, which is relativistic, individualistic and emotivistic, and also 'socially utilitarian': the citizen "accepts a new method of 'assessing' human actions based on two radically different criteria, which can only be lived to the extent that they remain in two completely different levels. He accepts the utilitarian system of social valuation that seeks to maximize the results according to objective measures that permit the comparison of interests [the economic and social goals: welfare, growth, security, etc.] [...] Moreover, the inner world of private emotions identified as 'feeling good', which happens to occupy the entire field of consciousness" (Pérez-Soba 2011, pp. 7-8).

In the end, moral contents are transferred to the law, which then becomes a source of ethical norms. In an individualistic society, in which common goods are not feasible, the majority rule becomes a moral criterion. This leaves the individual faced with a previously unknown freedom of choice, but plunged into uncertainty, which is then discharged into the law: what the law allows is good, what it prohibits is bad, and if this is displeasing, the individual can demand the

22 This has led, it seems, to a crisis of legitimacy of the system (Habbu 2011). 
recognition of the right to disagree, which can lead to the exception becoming a new standard. The State eventually takes previously private behaviors and makes them obligatory moral standards. "Hyper-judicialized societies, like the present one, favor the assumption of decreed obligations (as well as the claim of rights) but not of responsible actions towards the future. Responsibility is a term that always appears whenever injury or damage occurs; these are, in every case, anonymous, legal, and institutional responsibilities, with respect to the past, and for this there is the State, insurance, etc." (Flamarique 2010, p. 110).

Polo (1996b) outlines some of the consequences of applying purely technical solutions to human, i.e., ethical problems: 1) segmentation, the result of a lack of a comprehensive overview, which results from the specialization and one-sidedness of the 'experts' (the proposed economic solutions to the crisis are not operational because they omit other dimensions: political, sociological, psychological and ethical); 2) perverse effects, which can occur in other areas, because we are not able to organize the means without causing dangerous side effects, because we have no unconditional principles from which we can deploy practical action, and because we cannot guarantee the consistency of our uncoordinated projects (the explosion of systemic risk in the crisis may be an example of this); 3) anomie, the state of discouragement of those who have no course of action, but only stimuli; and 4) social entropy: institutions lose their function.

Can there be an objective ethics, capable of validating public and private behavior in the financial world? If what we have said so far is at least an approximate description of our moral environment, then the answer is no. The proposed solutions to the crisis overlook its ethical dimension, and seek only technical solutions, such as the reform of regulatory and supervisory frameworks, which are based, in any case, on results-oriented consequentialist ethics, or on results-oriented public ethics, which just add a spurious moral dimension to public decisions.

In summary, we believe that the failures in the conduct of financial institutions, regulatory bodies and governments which the crisis has highlighted were not isolated events but rather point to flaws in the anthropological and ethical models that have governed the conduct not only of those agents, but much of our society, at least in developed countries. That is to say, models built from incomplete or erroneous assumptions led to wrong managerial approaches: in incentive, monitoring, reporting and accounting systems; in the selection, training and compensation of human capital; and in the organizations' very culture. ${ }^{23}$ And with these wrong approaches, one could only reasonably expect the proliferation of misguided behaviors such as greed, recklessness, pride, fraud, dishonesty, etc., as well business objectives, control systems, cultures, incentive systems and rules of conduct that, ultimately, resulted in this crisis.

\section{Conclusion}

We wondered earlier whether it is possible, in the financial world, to conceive of an objective ethics that would be able to validate public and private behavior. By observing our advanced societies, we reached a negative conclusion... but that was too hasty. This is not the right place to develop how an ethical conception should be, if it is to correct the problems created by the crisis and prevent their recurrence; but we can at least make some suggestions.

\footnotetext{
${ }^{23}$ See the excellent explanation in Sahlman (2009).
} 
There should not be a different ethic for the economy, for politics and for individuals; ethical schizophrenia leads to inconsistency and, concretely, to the systemic crisis of the person (a person who is utilitarian in social life and emotivist in private life, who demands external results as a moral requirement, but does not accept personal responsibility for their achievement), organizations, and society as a whole. The economic system, in particular, is not self-regulating: market stability requires a legal and regulatory system, but this is not enough. The existence of traffic rules and physical barriers does not guarantee safe and smooth driving on the highways, if drivers break the rules at a cost to others, or if those who make and change the rules do so for objectives other than the welfare of citizens.

The reader will certainly object that there already exist ethical rules in our societies, and that, nevertheless, they were not been able to avert the crisis. But this has probably been because not all ethics are equally effective. Ethics must be based on the actions of rational people in a social setting (Abbà 1992, Argandoña 2011, Den Uyl 2009). This excludes, first, some ethics focused on obtaining results, which forget that the most important result is people learning; second, individualistic ethics, which does not sufficiently take into account that the person is social, growing in his relations with others and learning from them and with them; and, thirdly, ethics that focus only on actions as separate units, and which do not account for the learning processes (development of virtues) that we mentioned earlier.

Ethics is the equilibrium condition of individuals, organizations and societies. This equilibrium is dynamic, because whenever an action takes place, the agent undergoes a change and produces changes in others, so that what is an equilibrium now may cease to be an equilibrium tomorrow. This is what we mean when we say that ethics is the condition of equilibrium. Therefore, ethics based on external rules (laws, social norms or corporate codes), and not based on the acting person, may not be good guides for action. This does not mean that norms do not have an important role: we definitely need an ethic of virtues (that explains how the agent improves or worsens in his actions, and how he develops or hinders the ability to behave ethically in the future), goods (which is what the agent should achieve) and norms (which should be observed to not deteriorate as a person but rather to improve as a person) (Polo 1996a).

All this leads to two further conclusions. First, ethics cannot be separated from economics. There are no economic decisions or ethical decisions: there are only decisions that are, at the same time, economic, ethical and political. Economics deals with means, but not means for given goals, because ethics governs the goals. The thesis of separation between economics and ethics is one of the ultimate causes of the crisis. And second, for the same reason, politics should be tightly linked with ethics - and, again, the omission of this relationship has a lot to do with the current crisis.

Purely economic interpretations of the crisis are not necessarily wrong, but they are incomplete because they omit at least some important consequences of the decision-maker's decisions on himself (because he learns to act either well or poorly), on others (who also learn) and on the organization (in which moral or immoral cultures are created, and in which trust is promoted or destroyed). Ethics must add a richer conception of the person to the economy, providing explanations that are not necessarily different but more complete, in which one can better outline the consequences of decisions, not only in economic terms. And this will serve to better identify problems, to better understand the nature of the failures that have occurred and to offer better solutions. But these solutions will not be developed by the moralist, but by the economist, taking into account the criteria of ethics. 
Ethics has three dimensions: personal, organizational and social. The solution to the problems created by the crisis demands an ethical response at these three levels. People should be ethical, organizations must act in accordance with ethics, and society should behave ethically. And this has both theoretical (what is ethics and how does it relate to economics and politics) and practical aspects (how to spread behaviors and how to create the conditions wherein policy and institutional constraints can block unethical actions). All three dimensions are needed.

"While the music plays, you have to dance," said Charles ("Chuck") Prince, CEO of Citigroup, in the Financial Times in July 2007. He added: "We're still dancing." This phrase summarizes the situation for many financial institutions in recent years: a riotous dance, from which, like the game of musical chairs, no-one could withdraw. "These words are now the epitaph of the global credit boom". ${ }^{24}$

\footnotetext{
${ }^{24}$ Mackenzie (2009).
} 


\section{References}

Abbà, G. (1992), Felicidad, vida buena y virtud, Barcelona, Ediciones Internacionales Universitarias.

Abberger, K. and W. Nierhaus (2008), “How to define a recession?”, CESifo Forum, 4, pp. 74-76.

Acemoglu, D. (2009), “The crisis of 2008: Structural lessons for and from economics”, MIT, January.

Aranzadi, J. (2006), Liberalism against Liberalism. Theoretical Analysis of the works of Ludwig von Mises and Gary Becker, London, Routledge.

Argandoña, A. (2009), "Crisi financera: a la recerca de criteris ètics”, in La situació econòmica global. A la recerca d'uns criteris ètics, Barcelona, Facultat de Teologia de Catalunya, pp. 77-96.

Argandoña, A. (2010a), “¿Puede la responsabilidad social corporativa ayudar a entender la crisis financiera?”, in M. A. Arráez and P. Francés (eds.), Ética y Responsabilidad ante la Crisis, Granada, Ediciones Sider, pp. 51-83.

Argandoña, A. (2010b), "La dimensión ética de la crisis financiera”, in A. Costas (ed.), La crisis de 2008. De la economía a la politica y más allá, Almería, Fundación Cajamar, pp. 183-198.

Argandoña, A. (2010c), "Más allá de la eficiencia: Lecciones éticas de la crisis para la cultura empresarial”, in T. Jiménez Araya (ed.), Hacia una nueva ética económica global. Innovación vs. statu quo, Barcelona, Huygens Editorial, pp. 203-226.

Argandoña, A. (2011), "Las virtudes en una teoría de la acción humana”, in P. Requena and M. Schlag (eds.), La persona al centro del Magistero sociale della Chiesa, Roma, Edusc, pp. 49-71.

Baily, M. N., R. E. Litan and M. S. Johnson (2008), "The origins of the financial crisis", Washington, DC, Brookings Institution, Fixing Finance Series Paper 3.

Bhattacharya, U. and X. Yu (2008), "The causes and consequences of recent financial market bubbles: An introduction”, The Review of Financial Studies, 21, pp. 3-10.

Blundell-Wignall, A., P. Atkinson and S. Hoon Lee (2008), "The current financial crisis: causes and policy issues", Financial Market Trends, Paris, OECD.

Bogle, J. (2006), "The depth and breadth of the financial scandals", Challenge, 49, pp. 23-32.

Bordo, M. D. (2008), "A historical perspective of the crisis of 2007-2008”, Cambridge, MA, National Bureau of Economic Research, NBER Working Paper No. 14659.

Brunnermeier, M. K. (2008), “Deciphering the liquidity and credit crunch 2007-2008", Cambridge, MA, National Bureau of Economic Research, NBER Working Paper No. 14612.

Caballero, R. J. (2010), "Macroeconomics after the crisis: Time to deal with the pretense-ofknowledge syndrome”, Journal of Economic Perspectives, 24, 4, pp. 85-102.

Claessens, S., M. Ayhan Kose and M. E. Terrones (2008), "What happens during recessions, crunches and busts?", Washington, DC, International Monetary Fund, IMF Working Paper $\mathrm{WP} / 08 / 274$. 
Coleman, L. and S. Pinder (2010), "What were they thinking? Reports from interviews with senior finance executive in the lead-up to the GFC", Applied Financial Economics, 20, pp. 7-14.

Crotty, J. and G. Epstein (2008), "Proposals for effectively regulating the U.S. financial system to avoid yet another meltdown", Amherst, MA, University of Massachusetts, Department of Economics, Working Paper 2008-15.

Den Uyl, D. J. (2009), “Homo moralis”, Review of Austrian Economics, 22, pp. 349-385.

Diamond, D. W. and R. Rajan (2009), "The credit crisis: Conjectures about causes and remedies", Cambridge, MA, National Bureau of Economic Research, NBER Working Paper No. 14739.

Eichengreen, B. (2008), “Origins and responses to the current crisis”, CESifo Forum, 4, pp. 6-11.

Flamarique, L. (2009), "Emociones versus normas. El confinamiento psicológico de la experiencia social”, Pensamiento y Cultura, 12, 2, pp. 321-339.

Flamarique, L. (2020), “En 1989 terminó la era de las revoluciones y de las utopías socialistas, y nació una nueva cultura política”, Nuestro Tiempo, January-February, pp. 104-110.

Graafland, J. J. and B. W. van de Ven (2011), "The credit crisis and the moral responsibility of professionals in finance”, European Banking Center Discussion Paper No. 2011-012.

Greenspan, A. (2007), The Age of Turbulence: Adventures in a New World, New York, NY, Penguin Press.

Gross, D. (2007), Pop! Why Bubbles Are Great for the Economy, New York, NY, HarperCollins.

Gross, D. (2009), Dumb Money: How our Greatest Financial Minds Bankrupted the Nation, New York, NY, Free Press.

Habbu, A. (2011), “The neoliberal legitimation crisis of 2008”, Carceral Notebooks, Paper No. 2.

Handy, C. (2002), “What is a business for?” Harvard Business Review, December, pp. 49-55.

Harris, J. D. and R. E. Freeman (2008), "The impossibility of the separation thesis", Business Ethics Quarterly, 18, 4, pp. 541-548.

Hawtrey, K. and R. Johnson (2009), "On the atrophy of moral reasoning in the global financial crisis”, Journal of Religion and Business Ethics, 1, 2, pp. 1-23.

Hellwig, M. (2008), “The causes of the financial crisis”, CESifo Forum, 4, pp. 12-21.

Hoffman, P. T., G. Postel-Vinay and J. L. Rosenthal (2007), Sustaining Large Losses, Cambridge, MA, Harvard University Press.

Jonas, H. (19084), The Imperative of Responsibility: In Search of Ethics for the Technological Age, Chicago, IL, University of Chicago Press.

Kane, E. J. (2008), "Ethical failures in regulating and supervising the pursuit of safety net subsidies", Terre Haute, IN, Indiana State University, Networks Financial Institute Working Paper 2008-WP-12.

Kay, J. (2009a), “Introduce professional standards for senior bankers”, Financial Times, 18 February.

Kay, J. (2009b), "Greenspan could have found a cure at the pharmacy”, Financial Times, February. 
Kerr, S. (1975), "On the folly of rewarding A while hoping for B", Academy of Management Journal, 18, pp. 769-783.

Keynes, J. N. (1890), The Scope and Method of Political Economy, London, Macmillan.

Kindleberger, C. P. (1978), Manias, Panics and Crashes: A History of Financial Crises, New York, NY, John Wiley and Sons; 2nd ed. (con Robert Z. Aliber) 2005.

Levine, R. (2010), “An autopsy of the U.S. financial system”, Cambridge, MA, National Bureau of Economic Research, NBER Working Paper No. 15956.

Lo, A. W. (2008), "Hedge funds, systemic risk, and the financial crisis of 2007-2008", Washington DC, U.S. House of Representatives Committee on Oversight and Government Reform, November 13.

MacIntyre, A. (1981), After Virtue. A Study of Moral Theory, Notre Dame, IN, Notre Dame University Press.

MacIntyre, A. (1995), Marxism and Christianity, London, Duckworth.

Mackenzie, M. (2009), "Cautionary tale from Citi for new giants of finance", Financial Times, 17 January.

Mendoza, E. and M. E. Terrones (2008), "An anatomy of credit booms: Evidence from macro aggregates and micro data”, Cambridge, MA, National Bureau of Economic Research, NBER Working Paper No. 14444.

Miller, R. T. (2009), "Morals in a market bubble", University of Dayton Law Review, 35, 1, pp. 113-137.

Morris, C. R. (2008), The Trillion Dollar Meltdown. Easy Money, High Rollers, and the Great Credit Crash, London, Public Affairs.

Pérez-Soba, J. J. (2011), "La renovación moral en la vida económica”, in the Symposium on Social Doctrine of the Church. Madrid, Fundación Pablo VI, June.

Pezzuto, I. (2008), "Miraculous financial engineering or toxic finance? The genesis of the United States subprime mortgage loans crisis and its consequences on the global financial markets and the real economy", Swiss Management Center Working Paper No. 12/2008.

Pieper, J. (1966), The Four Cardinal Virtues: Prudence, Justice, Fortitude, Temperance, Notre Dame, IN, University of Notre Dame Press.

Polo, L. (1991), Quién es el hombre. Un espiritu en el mundo, Madrid, Rialp, 1991.

Polo, L. (1993), “La ética y las virtudes del empresario. Entrevista a Leonardo Polo”, Atlántida, 14, pp. 80-92.

Polo, L. (1996a), Ética. Hacia una versión moderna de los temas clásicos, Madrid, Unión Editorial.

Polo, L. (1996b), Sobre la existencia cristiana, Pamplona, Eunsa.

Robbins, L. (1935), An Essay on the Nature and Significance of Economic Science, London, Macmillan. 
Rosanas, J. M. (2006), "Indicadores de gestión, incentivos, motivación y ética en el control de gestión”, Barcelona, IESE Business School, Occasional Paper, OP 06/11.

Rosanas, J. M. and M. Velilla (2003), "Loyalty and trust as the ethical bases of organizations", Journal of Business Ethics, 44, pp. 49-59.

Sahlman, W.A. (2009), "Management and the financial crisis (We have met the enemy and he is us...)", Boston MA, Harvard Business School, Working Paper 10-033.

Sinn, H. W. (2008), "The end of the wheeling and dealing", CESifo Forum, 4, pp. 3-5.

Solomon, B. (1992), Ethics and Excellence. Cooperation and Integrity in Business, New York, NY, Oxford University Press.

Taleb, N. N. (2007), The Black Swan: The Impact of the Highly Improbable, New York, NY, Random House.

Taylor, Ch. (1989), Sources of the Self. The Making of the Modern Identity, Cambridge, Cambridge University Press.

Taylor, J. B. (2009a), "The financial crisis and the policy responses. An empirical analysis of what went wrong”, Cambridge, MA, National Bureau of Economic Research, NBER Working Paper No. 14631.

Taylor, J. B. (2009b), Getting Off Track. How Government Actions and Interventions Caused, Prolonged, and Worsened the Financial Crisis, Stanford, CA, Hoover Institution Press.

Termes, R. (1995), "Ethics in financial institutions", in A. Argandoña (ed.), The Ethical Dimension of Financial Institutions and Markets, Berlin, Springer Verlag, pp. 118-135.

Tett, G. (2009), Fool's Gold. How Unrestrained Greed Corrupted a Dream, Shattered Global Markets and Unleashed a Catastrophe, London, Little Brown.

Torres, M. (2009), "Getting business off steroids", in Friedland, J. (ed.), Doing Well and Good: The Human Face of New Capitalism, Charlotte, NC, Information Age Publishing.

Zamagni, S. (2009), "The lesson and warning of a crisis foretold: a political economy approach", International Review of Economics, 56, pp. 315-334. 